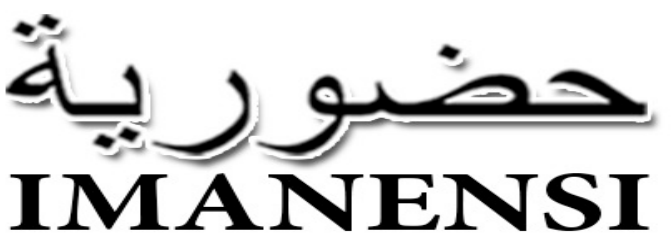

Jurnal Ekonomi, Manajemen, dan Akuntansi Islam

Vol 4, No 2, September 2019, Hlmn. 1-8

\title{
Dimensi ketuhanan dalam pendidikan akuntansi
}

\section{Nurhudaa,1,*, Novanda Eka Saputrab,2, Hendrika Betani Hernanda ${ }^{c, 3}$, Elana Era Yusdita ${ }^{d, 4}$}

abcd Universitas PGRI Madiun, Jl. Setia Budi no 85 Madiun, Indonesia, 63118

1noerhuda35@gmail.com*; 2novandaeka9@gmail.com;

3 hernandabeta@gmail.com; elaradita@unipma.ac.id4

* penulis koresponden

\begin{abstract}
Abstrak
Penelitian ini bertujuan untuk mengetahui bagaimana seorang tenaga pendidik dalam menghadirkan dimensi ketuhanan dalam proses pembelajaran. Metode yang digunakan adalah metode kualitatif dengan berlandaskan pada paradigma interpretif dan pendekatan etnometodologi. Hasil penelitian ini disimpulkan bahwa upaya yang dilakukan tenaga pedidik dalam menghadirkan dimensi ketuhanan adalah dengan acara mengawali setiap aktivitas dengan doa dan mengkonstruksi hukum fiqih terhadap materi yang disampaikan. Upaya tersebut dilakukan untuk meningkatkan kesadaran spiritual (SQ) mahasiswa agar terhindar dari berbagai bentuk penyimpangan terhadap nilai, norma, maupun kode etik profesi yang pada akhirnya merugiakan nama baik profesi, masyarakat maupun negara.
\end{abstract}

Kata Kunci: Ketuhanan; Pembelajaran; Kecerdasan Spiritual

\begin{abstract}
This study aims to find out how an educator presents a divine dimension in the learning process. The method used is a qualitative method based on the interpretive paradigm and ethnometodology approach. The results of this study concluded that the efforts made by educators in presenting the divine dimension were through praying activity before the learning process began and construct the law of jurisprudence on the material presented. These efforts were carried out to increase student awareness to avoid various forms of deviation from the values, norms, and professional codes of ethics which ultimately harmed the name of both the profession, society and the state.
\end{abstract}

Keywords: Pembelajaran; Learning Progress; Spiritual Quotient

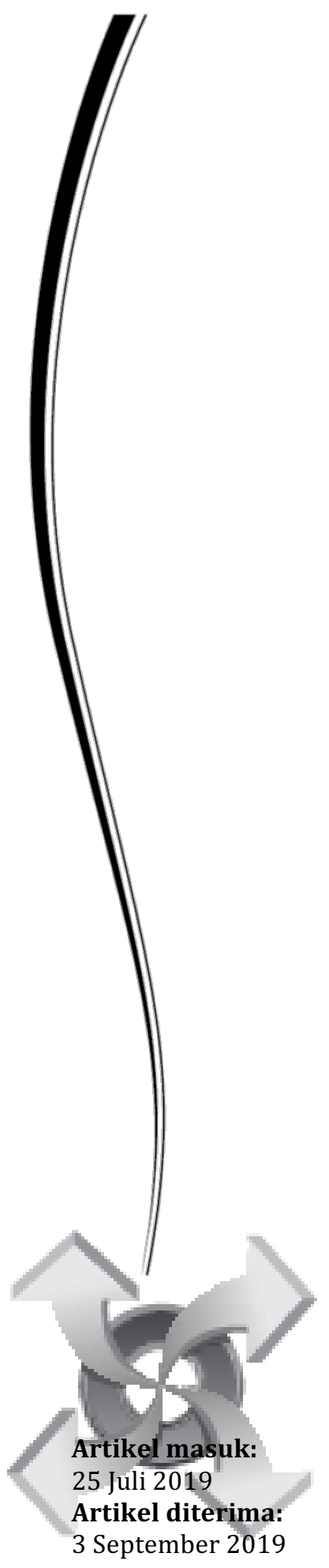




\section{PENDAHULUAN}

Pendidikan merupakan cara yang dapat digunakan untuk mengangkat derajat generasi bangsa dan menjadi sebuah dasar untuk pembentukan karakter akuntan yang di samping profesional juga memiliki karakter yang unggul (Musmini \& Aneswari, 2017). Pendidikan karakter merupakan sebuah usaha yang dilakukan untuk menanamkan kebiasaan/ budaya yang baik, dengan demikian peserta didik dapat bertindak dan bersikap sesuai dengn nilai-nilai yang berlaku (Rachmah, 2013).

Melalui sebuah pendidikan peserta didik diajak untuk mengasah kemampuan berfikirya oleh pendidik. Di samping untuk melatih kemampuan berfikir pendidik, untuk memberikan keseimbangan bagi peserta didik dalam mengolah pikir, rasa, hati dan raga, seorang pendidik juga harus memberikan berbagai macam pembelajaran yang dapat mengasah kemampuan berfikir dan kemampuan emosi serta spiritual peserta didik untuk membentuk karakter yang di samping cerdas juga diimbangi dengan karakter yang baik. Terlebih dalam bidang pendidikan akuntansi, di samping figur guru yang melekat pada bidang ini juga terdapat tantangan lain yang menuntut agar lulusan pendidikan akuntansi dapat menyalurkan ilmunya secara lebih bermakna. Sehingga, dapat disimpulkan bahwa proses mengajar merupakan bagian dari serangkaian fase transfer ilmu yang akan terus berputar. Apa yang diajarkan sekarang akan disampaikan kembali oleh peserta didik melalui profesinya sebagai seorang guru. Oleh karena itu, pembentukan guru akuntansi yang profesional dan berintegritas sudah barang tentu harus dimulai mulai dari jenjang S1 agar dapat dihasilkan guru-guru akuntansi yang sadar akan perasn dan tugasnya sebagai seorang tenaga pendidik. Apa yang di sampaikan yang pada akhirnya membentuk kecerdasan peserta didik. Apa yang dicontohkan yang pada akhirnya dicontohkan oleh peserta didik. Dengan demikian peran seorang dosen memegang peran yang besar dalam proses pembentukan diri peserta didik. Hal tersebut, dianalogikan oleh (Yusdita, 2014) bahwa jika sebuah tanaman adalah sebuah profesi seorang akuntan maka kebermanfaatannya ada pada keteduhan dedaunannya, wanginya berada pada keharuman bunganya, kelezatannya ada pada buahnya, dan akarnya yang merupakan analogi dari sebuah etika, pupuk yang diberikan adalah ilmu yang diberikan oleh tenaga pendidik, dan yang memupuk adalah tenaga pendidik itu sendiri. Semakain tanaman itu dipupuk dengan penuh kasih sayang dan waktu yang tepat maka akan menghasilkan tanaman yang subur dan mampu menghasilkan buah. Analogi tersebut menyimpan berbagai makna bahwa tenaga pendidik menjadi salah satu penentu keberhasilan seorang pendidik. Apa yang diberikan oleh tenaga pendidik akan berdampak pada pengembangan diri pendidik. Sriani (2015) menambahkan jika peran dan sikap tenaga pendidik sangat berpengaruh sebagai student leadership, yakni tenaga pendidik harus dapat menjadi pemimpin yang dicintai oleh peserta didik, tenaga pendidik harus menjadi pemimpin yang di percaya oleh peserta didik, tenaga pendidik harus dapat menjadi pemimpin yang memiliki kepribadian. Dengan demikian apa yang dicontohkan seorang pendidik yang pada akhirnya membentuk karakter yang sama.

Sebagai seorang lulusan Akuntan mahasiswa diharapkan bukan hanya pandai dalam menyusun laporan keuangan, akan tetapi juga pandai dalam mengolah rasa dalam menyajikan laporan keuangan tersebut. Di saat mahasiswa memperoleh sebuah gelar Akuntan, mereka diharapkan agar mampu berpraktik dengan bekal etika yang kuat dan nilai-nilai moral yang terinternalisasi dalam dirinya (Musmini \& Aneswari, 2017). Lalu dimanakah 
letak nilai-nilai etika dan moral itu disampaikan? Sriani (2015) menjelaskan bahwa peran pendidik sebagai manajer pembelajaran harus diimbangi dengan tiga kecerdasan diantaranya, kecerdasan intelektual (IQ), kecerdasan emosional (EQ), dan kecerdasan spiritual (SQ). Keseimbangan tiga aspek tersebut sangat diperlukan karena SQ dibutuhkan menjalankan fungsi IQ dan EQ, dengan demikian SQ merupakan kecerdasan tertinggi yang ada apada manusia.

Dalam dunia pendidikan akuntansi menanamkan akan adanya dimensi Tuhan dalam proses pembelajaran menjadi salah satu upaya yang dapat dilakukan untuk mengasah kecerdasan spiritual mahasiswa. Kecerdasan ini penting untuk diinternalisasikan pada diri mahasiswa terkhusus mahasiswa pendidikan akuntansi agar mahasiswa juga sadar akan fitrahnya sebagai manusia yang bukan hanya diberikan otak untuk berfikir, akan tetapi di sisi lain manusia juga diberikan fitrah berupa hati/qalbu yang juga harus dimaksimalkan untuk merasa. Dengan sadarnya mahasiswa akan adanya dimensi Tuhan inilah yang diharapkan mahasiswa paham bahwa segala yang dilakukan ada Tuhan yang senantiasa mengawasi dan melihat setiap apa yang dikerjakannya. Dalam islam dijelaskan bahwa:

Dialah yang menciptakan langit dan bumi dalam enam masa, kemudian Dia bersemayam di atas 'arsy. Dia mengetahui apa yang masuk ke dalam bumi dan apa yang keluar daripadanya dan apa yang turun dari langit dn apa yang naik kepada Nya, dan Dia bersama kamu di mana saja kamu berada. Dan Allah maha melihat apa yang kamu kerjakan. (Q.S. Al-Hadid: 4)

Dalam ayat yang lain dijelaskan:

Tidaklah kamu perhatikan, bahwa sesungguhnya Allah mengetahui apa yang ada di langit dan di bumi? Tiada pembicaraan rahasia antara tiga orang, melainkan Dia lah keempatnya. Dan tiada (pembicaraan antara) lima orang, melainkan Dialah keenamnya. Dan tiada (pula) pembicaraan antara jumlah yang kurang dari itu atau lebih banyak, melainkan Dia berada bersama mereka di manapun mereka berada. Kemudian Dia akan memberitahukan kepada mereka pada hari kiamat apa yang telah mereka kerjakan. Sesungguhnya Allah maha mengetahui segala sesuatu. (Q.S. Al Mujadillah: 7).

Kesadaran inilah yang diharapkan mampu dihasilkan dari upaya mengolah kecerdasan spiritual mahasiswa agar mahasiswa senantiasa menerapkan karakter tersebut dalam dunia kerja setelah lulus dari bangku perkuliahan. Sadar akan adanya Tuhan yang senantiasa mengawasi setiap tingkah laku manusia diharapkan menjadi dasar dalam berbuat, bersikap dan bertingkah laku. Sehingga, dengan adanya kesadaran tersebut dapat meminimalisir setiap pelanggaran nilai, norma maupun kode etik profesi yang merugikan bukan hanya nama baik profesi akan tetapi juga masyarakat, bangsa dan negara. Oleh karena itu, melalui pendekatan etnometodologi dalam penelitian ini akan ditelusuri bagaimana seorang pendidik dalam dunia akuntansi menanamkan nilai spiritual pada peserta didiknya untuk menyeimbangkan antara IQ, EQ dan SQ mahasiswa.

\section{METODE}

Metode penelitian menjadi salah satu cara yang digunakan peneliti untuk mencari sekaligus menginterpretasi data hasil temuan. Dalam penelitian ini digunakan metode penelitian kualitatif dengan paradigma interpretivis dan menggunakan sebuah pendekatan etnometodologi. Etnometodologi merupakan metode yang sekuer, dikarenakan kebenran induktif semata-mata menjadi kebenaran pengetahuan (Kamayanti, 2016). Dalam sebuah penelitian etnometodologi, tahap pertama yang harus 
dilaksanakan seorang peneliti adalah dengan cara menganalisis indeksikalitas data hasil temuan. Indeksikalitas merupakan suatu esensi atau tema dari sebuah topik pembahasan. Tahapan yang kedua dalam sebuah penelitian etnometodologi adalah dengan menganalisis reflektivitas. Dimana setelah peneliti mengamati keseharian kelompok sosial peneliti harus menemukan ekspresi indeksikalitasnya dan selanjutnya menelaah dengan merefleksikan ekspresi tersebut. (Kamayanti, 2016). Subyek penelitian adalah kelompok kelas pendidikan akuntansi di sebuah perguruan tinggi swasta Di Jawa Timur. Sedangkan teknik pengumpulan data yang digunakan adalah melalui observasi/pengamatan, wawancara dan dokumentasi. Jenis penelitian kualitatif digunakan karena melalui metode ini akan diperoleh informasi secara lebih mendalam dan dapat menyingkap keseharian dari sebuah kelompok sosial.

\section{HASIL DAN PEMBAHASAN}

\section{A. Semoga Keselamatan dan Rahmat Allah, Serta Keberkahan-Nya Terlimpah kepada Kalian.}

"Assalamu'alaikum warahmatullahi wabarakatuh." (Bu EY). Ucapan tersebut yang kerap kali disampaikan seorang muslim kepada muslim lainnya. Ucapan salam tersebut menjadi sebuah identitas sekaligus simbol manusia muslim ketika bertemu dengan muslim lainnya. Ucapan salam bukan hanya sekedar sapaan atau hanya sebatas prosesi sebelum melaksanakan sebuah kegiatan, akan tetapi di dalam nya menyimpan sebuah doa dan harapan yang di sampaikan. Makna ucapan salam bukan hanya sebatas sebagai identitas muslim akan tetapi di dalamnya terkandung sebuah nilai sosial yang amat tinggi. sudah menjadi kewajiban seorang muslim untuk mendoakan sesama muslim lainya. Ucapan salam inilah yang menjadi sarana mendoakan sesama muslim yang dapat dilakukan di semua tempat tanpa adanya batasan waktu.

"Semoga keselamatan dan rahmat Allah serta keberkahan-Nya terlimpah kepada kalian.”. Jika dilihat dari segi maknanya ucapan salam ternyata menyimpan makna yang sangat mendalam, dimana tersirat di dalamnya akan kepedulian sosial antar manusia sesama muslim. Do'a menjadi sebuah pengharap akan adanya keselamatan dan kesejahteraan yang bukan hanya dirasakan sendiri akan tetapi berharap keselamatan dan kesejahteraan yang dirasakan oleh orang lain.

Dalam proses pembelajaran yang peneliti sudah amati bahwa ucapan salam juga tidak lepas dari serangkaian kegiatan belajar. Guru mengawali kegiatan pembelajaran dengan bacaan basmallah dan melanjutkannya dengan mengucapkan salam. Walaupun salam ini dianggap hal yang sepele dan menjadi hal yang biasa dilakukan, akan tetapi dibaliknya tersirat pesan lain yang ingin disampaikan oleh seorang dosen. Disamping kewajiban dosen sebagai pemeluk muslim yang harus mengucapkan salam kepada muslim lainnya, di samping itu terdapat makna kepedulian yang ingin dihadirkan dosen kepada mahasiswa sebelum mengawali kegiatan perkuliahan yang diawali dengan doa melalui perantara ucapan salam. Dosen memberikan contoh dengan melakukan pembiasaan mengucapkan salam kepada mahasiswa sehingga secara tidak sadar akan menghadirkan budaya salam sebelum melakukan sesuatu. Inilah salah satu bentuk usaha seorang pendidik dalam membangkitkan kesadaran mahasiswa untuk melatih kecerdasan spiritualnya melalui budaya mendoakan sesama muslim lainnya yang diharapkan mahasiswa dapat mengaktualisasikannya bukan hanya pada lingkup rung kelas akan tetapi juga direalisasikan di kehidupan sehari- 
hari mahasiswa. Sitorus (2015) menyatakan bahwa akuntansi spiritual hadir sebagai wujud kerendahan hati manusia dihadapan Tuhan. Melalui akuntansi yang didasarkan pada nilai spiritualitas manusia disadarkan bahwa manusia bukan siapa-siapa di hadapan tuhan, sehingga kebenaran yang sejati adalah kebenaran yang berasal dari Tuhan. Oleh karena itu, dalam kegiatan pembelajaran di kelas yang penulis amati dilakukan proses olah hati bahwa manusia sangat kecil jika dihadapkan dengan Tuhan.

\section{B. Upaya Menghadirkan Tuhan dalam Pembelajaran di Kelas}

"Audzubillahiminasyaitonirrojim bismillahirrohmanirrohim. Ya Tuhan kami yang maha pengasih lagi maha penyayang, berilah kami ilmu yang bermanfaat, semoga segala usaha yang kami usahakan maksimal, selama kuliah dapat menghasilkan hasil yang maksimal, serta dapat lulus tepat waktu. amin amin ya robbal'alamin..” (Bu EY).

Dalam keheningan doa yang dipanjatkan dosen ke mahasiswa terdengar harapan yang dimunajatkan dosen untuk semua mahasiswa sebelum kegiatan pembelajaran dimulai. Dalam suasana khusu' dosen berusaha menghadirkan Tuhan dalam kegiatan pembelajaran. Hal ini dilakukan dengan harapan kegiatan pembelajaran mendapatka ridho dari Tuhan. Doa dimulai dengan membaca ta'awudz "Audzubillahiminassyaitonirrajim" (Aku berlindung kepada Allah dari godaan syaitan yang terkutuk"). Ungkapan ini mengandung makna bahwa adanya harapan yang ingin disampaikan dosen agar pembelajaran dapat dilaksanakan dengan lancar. Pendidik dapat memberikan ilmu tanpa adanya gangguan dari syaitan yang menghambat mahasiswa dalam menerima setiap materi. Adanya bacaan Basmallah (Bismillahirrahmanirrakhim) menjadi simbol rasa syukur dosen karena dapat dipertemukan dengan mahasiswa untuk melaksanakan proses pembelajaran. di samping itu bacaan basamallah juga mengajarkan bahwa tiada Tuhan yang emberikan kesempata untuk bertatap muka secara langsungk kevuali Tuhanlah yang mengijinkan untuk dapat saling bertemu dengan nikmat kesehatan dan kesempatan yang telah diberikan sehingga dapat melaksanakan kegiatan belajar mengajar.

Upaya menghadirkan Tuhan dalam proses pembelajaran yang diaktualisasikan dengan kegiatan doa bersama sebelum melaksanakan kegiatan belajar mengajar ini, juga diterapkan oleh dosen untuk membentuk sebuah budaya pembiasaan mahasiswa agar mengawali setiap kegiatan dengan bacaan doa dan rasa syukur. Upaya mengadirkan Allah adalah sebuah penyadaran akan selalu mengingat Allah bahwa Allah tidak terbatas ruang dan waktu (Sari, 2016). Dengan adaya peran Tuhan di setiap aktivitas termasuk dalam proses belajar mengajar diharapkan dapat mengolah kesadaran mahasiswa akan adanya Tuhan di setiap aktivitas yang dilakukan, dengan demikian, benteng keimanan diletakkan pada poros yang utama sebelum proses pembelajaran yang secara intelektual diberikan dosen kepada mahasiswa.

Pola pembentukan karakter dengan berlandaskan keimanan ini diterapkan oleh pendidik untuk mencetak karakter religius oleh mahasiswa. Terlebih dalam konteks ini adalah mahasiswa pendidikan akuntansi. Dimana mayoritas ilmu yang diajarkan mengarah pada pola pikir yang materialistik, segala sesuatu diorientasikan terhadap laba dengan melakukan berbagai cara pengubahan metode dan praktinya. Hal tersebut juga disampaikan dalam Musmini \& Aneswari (2017) yang menyatakan bahwa saat ini akuntansi yang diajarkan dalam pendidikan akuntansi hanya menekankan pada bottom line laba dan mengutamakan nilai-nilai sekularitas, yang pada akhirnya 
membentuk mahasiswa hanya memahami kepentingan ekonomi. Mahasiswa diajarkan bagaimana cara mengolah sebuah hanya keuangan tanpa memperdulikan hal tersebut dibenarkan dalam akidah atau tidak. Jika pola pembelajara seperti ini terus dilakukan tnpa diiringi dengan sisipan nilai spiritual bahwa ada Tuhan yang senantiasa mengawasi maka pada akhirnya akan melahirkan individu-individu yang hanya berorientasi pada laba tanpa memperdulikan nilai dan norma yang berlaku baik pada agama maupun pola tatanan yang berada dalam masyarakat. Hal ini tentu akan berbahaya jika karaakter tersebut terus diterapkan dalam dunia kerja dimana tuntutan dan tekanan yang semakin tinggi. Oleh karena itu, upaya menghadirkan Tuhan dalam proses pembelajaran menjadi salah satu upaya yang digunakan dosen dalam mengasah kemampuan berfikir secara spiritualitas (SQ) mahasiswa agar mahasiswa dapat menyadari bahwa di setiap aktivitasnya terdapat dimensi Tuhan yang senantiasa mengawasi. Masing-masing individu sudah barang tentu akan merasakan kehadiran Tuhan yang berbeda-beda, adanya perbedaan tersebutlah yang pada akhirnya membentuk lapisan-lapisan kesadaran diri masing-masing individu (Triyuwono, 2013). Sehingga jika kesadaran sudah terbentuk, dapat menjadi benteng keimanan yang mendasari serta menghalang adanya praktik-praktik akuntansi yang sebernanya jika dilihat dalam perspektif agama sangat bertentangan dengan norma-norma yang berlaku.

\section{Kebermanfaatan adalah Esensi Pendidikan}

Dalam sebuah pembelajaran seorang dosen mendoakan mahasiswa agar ilmu yang diterima dapat bermanfaat. Manfaat disini bermakna bahwa definisi belajar dalam konteks ini bukan hanya bagaimana dosen mengajar untuk mahasiswa akan tetapi esensi mengajar adalah bagaimana mahasiswa mampu memahami apa yang diajarkan oleh dosen serta mampu mengaktualisasikan ilmu yang telah dietrima tersebut agar berguna bukan hanya untuk dirinya sendiri akan tetapi dapat berguna untuk orang lain. Yusdita, (2014) menjelaskan bahwa melakukan segala sesuatu yang dilandasi dengan penuh kesadaran pada akhirnya akan menghasilkan kebaikan dan kebermanfaatan bukan hanya untuk dirinya sendiri tetapi juga untuk orang lain. Terlebih dalam dunia akuntansi yang banyak mengajarkan praktikpraktik akuntansi. Potensi untuk menyajikan laporan keuangan yang telah disajikan untuk kepentingan salah satu pihak sangatah besar. Dengan harapan adanya kebermanfaatan inilah dosen sangat berharap kepada mahasiswa bahwa setiap ilmu yang telah diajarkannya dapat digunakan secara arif bukan untuk disalahgunakan, karena segala sesuatu pasti akan dipertanggungjawabkan di sisi-Nya. Sebagaimana dalam Al-Qur'an dijelaskan:

"Sesungguhnya pendengaran, penglihatan dan hati, semuanya itu akan diminta pertanggung-jawabannya.” (Q.S. Al Isra' : 36.)

Ilmu yang bermanfaat adalah ilmu yang disampaikan. Artinya ketika mahasiswa menerima ilmu bukan hanya sekedar untuk mendapatkan nilai saja, akan tetapi dari imu yang diperoleh tersebut mahasiswa dapat menyampaikannya kembali kepada orang lain. Dengan demikian, tingkatan pendidikan dapat dikatakan berhasil jika ilmu yang diperoleh selama proses pembelajaran dapat diimplementasikan oleh mahasiswa baik secara langsung melalui pendidikan formal maupun secara tidsk langsung. Oleh karena itu kebermanfaatan ilmu adalah salah satu esensi yang melandasi proses pembelajaran, bukan hanya bermanfaat bagi dirinya sendiri akan tetapi bermanfaat bagi lingkungan sekitar. 


\section{Nilai Fiqih yang Mengkonstruksi pada Pendidikan Akuntansi}

Dalam sebuah pertemuan dalam kelas, dosen membuka kegiatan pembelajaran Sistem Informasi Akuntansi, dengan materi sistem penggajian. Dosen menyampaikan materi dengan sebagaimana menyampaikan materi sebagaimana ketika mengajar. Sistem penggajian menjadi salah satu mateti kuliah pendidikan akuntansi yang menggali informasi tentang bagaimana suatu entitas merancang sebuah pengendaliani internal untuk entitasnya. Di sela-sela pembelajaran dosen menyampaikan sebuah pesan yang mengandung di dalamnya nilai fiqih yang di konstruksi melalui materi yang diajarakan pada pertemuan tersebut.

“... Dia sudah mencapai 200 jam, ternyata catatannya masih 150 jam. Jadi bagaimana? Keringatnya udah terlampau kering...” (Bu EY).

Dalam ungkapan tersebut tersirat sebuah pembelajaran bahwa terdapat ketidaksetujuan dosen yang tidak sepakat dengan sebuah sistem penggajian dimana sistem tersebut tidak memberikan hak seseorang dalam menerima sebuah upah dari perkerjaa yang telah diselesaikannya. Sistem tersebut bertentangan dengan hukum fiqih yang berbunyi:

"Berilah upah pekerja sebelum keringatnya kering" (HR. Ibnu Majah).

Melihat dari hadist tersebut dosen berupaya menyadarkan mahasiswa melalui sebuah ungkapan yang sebenarnya jika dirasakan ungkapan tersebut mengarahkan mahasiswa agar kritis dan sadar jika sistem penggajian yang digunakan oleh suatu entitas tersebut bertentangan dengan hukum islam. Upaya ini sekaligus menjadi alat bagi dosen untuk melatih kemampuan spiritualitasnya agar kritis terhadap sebuah fenomena yang jika dilihat dari perspektif agama hal tersebut bertentangan. Dalam ungkapan tersebut dosen berusaha mengasah kemampuan spiritual mahasiswa agar mahasiswa sadar dengan keyakinan yang dianutnya dengan berbagaimacam sistem yang ada dalam sebuah literatur. Hal ini dilakukan dosen sebagai salah satu bentuk untuk menyeimbangkan kecerdasan mahasiswa dari sisi spiritualitasnya.

\section{SIMPULAN}

Upaya mengasah kecerdasan spiritual (SQ) mahasiswa dilakukan dosen dalam proses pembelajaran di dalam kelas pendidikan akuntansi telah dilakukan di dalam kelas. Ruang kelas menjadi salah satu wadah untuk membentuk pribadi mahasiswa yang disamping memiliki kecerdasan intelektual juga digunakan sebagai sarana untuk membangun kecerdasan spiritualitas mahasiswa, dimana kecerdasan spiritual (SQ) merupakan tingkatan kecerdasan tertinggi yang digunakan untuk memfungsikan kecerdasan yang lainya. Upaya ini dilakukan oleh dosen dengan cara menghadirkan dimensi Tuhan dalam proses pembelajaran akuntansi diantaranya adalah dengan acara mengawali setiap aktivitas dengan doa, dan mengkonstruksi hukum fiqih terhadap materi yang disampaikan. Upaya ini dilakukan untuk menyadarkan mahasiswa bahwa disetiap aktivitas ada dimensi Tuhan di dalamnya, sehingga akan menjadi pondasi yang membentengi mahasiswa dalam bertindak, berbuatdan bertingkah laku. Terlebih jika mahasiswa telah selesai melakukan pembelajaran dalam bangku perkuliahan dan melanjutkan kehidupan dalam dunia kerja, kesadaran itu diharapkan dapat terus diimplementasikan oleh mahasiswa untuk menghindari penyimpangan terhadap nilai, norma, maupun kode etik profesi yang pada akhirnya merugiakan nama baik profesi, masyarakat maupun negara. 


\section{REFERENSI}

Al Qur'an dan Terjemahannya. (n.d.).

Kamayanti, A. (2016). Metodologi Penelitian Kualitatif Akuntansi. Malang: Yayasan Rumah Peneleh.

Musmini.S.L \& Aneswari. Y.R. (2017). Quo vadis 1 Pancasila Dalam pendidikan di Indonesia? 8(1), 149-165.

Rachmah, H. (2013). Nilai-Nilai Dalam Pendidikan Karakter Bangsa Yang. EJurnal Widya Non-Eksakta, 1(1), 7-14. Retrieved from https://s3.amazonaws.com/academia.edu.documents/56942917/134File_Utama_Naskah-387-1-1020130923.pdf?AWSAccessKeyId=AKIAIWOWYYGZ2Y53UL3A\&Expires $=15$ 53361841\&Signature=FLdZnP95RmAVRw7\%2BylhrAXrdSz0\%3D\&respon se-content-disposition=inline\%3B filename\%3DNILAI-

Sari, A. F. K. (2016). Menelusuri nilai spiritual dalam proses pembelajaran akuntasi syariah.

Sitorus, J. H. E. (2015). Membawa Pancasila dalam Suatu Definisi Akuntansi. Jurnal Akuntansi Multiparadigma, 6(2), 254-271. https: //doi.org/10.18202/jamal.2015.08.6021

Sriani. (2015). Urgenci Keseimbangan Iq, Eq, Sq Pendidik dalam Proses Manajemen Pembelajaran. Nur El-Islam, 02(01), 55-77.

Triyuwono, I. (2013). [Makrifat] Metode Penelitian Kualitatif [ Dan Kuantitatif] Untuk Pengembangan Disiplin Akuntansi. Simposium Nasional Akuntansi Ke-16 Manado, (September), 1-15. https://doi.org/10.1016/j.tetlet.2010.08.113

Yusdita, E. E. (2014). Pendebetan Etika Dalam Jiwa Akuntan Indonesia: Pemupukan Nilai Pancasila Oleh Pendidik. Media Mahardhika, 12(3), 2840. 